
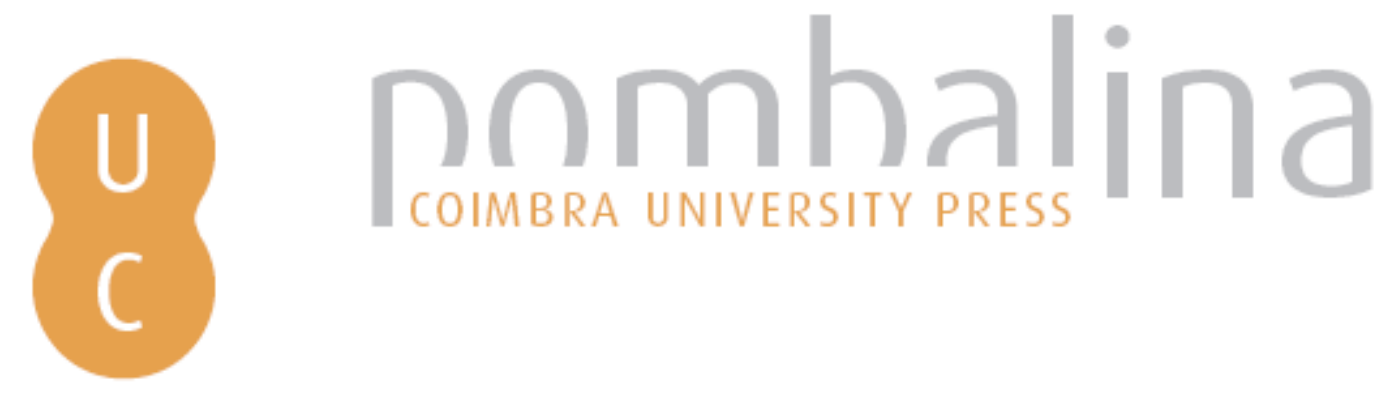

\title{
Erythropoietin doping as cause of sudden death in athletes: an experimental study
}

\author{
Autor(es): $\quad$ Sereno, J.; Pinto, A. F.; Costa, E.; Belo, L.; Santos-Silva, A.; Pinto, R.; \\ Couceiro, P.; Neto, P.; Xavier, F.; Carvalho, L.; Teixeira, F.; Reis, F.
}

Publicado por: $\quad \begin{aligned} & \text { Imprensa da Universidade de Coimbra; International Academy of Legal } \\ & \text { Medicine }\end{aligned}$

URL

persistente:

URI:http://hdl.handle.net/10316.2/31832

DOI:

DOI:http://dx.doi.org/10.14195/978-989-26-0173-1_47

Accessed : $\quad$ 26-Apr-2023 09:41:27

A navegação consulta e descarregamento dos títulos inseridos nas Bibliotecas Digitais UC Digitalis, UC Pombalina e UC Impactum, pressupõem a aceitação plena e sem reservas dos Termos e Condições de Uso destas Bibliotecas Digitais, disponíveis em https://digitalis.uc.pt/pt-pt/termos.

Conforme exposto nos referidos Termos e Condições de Uso, o descarregamento de títulos de acesso restrito requer uma licença válida de autorização devendo o utilizador aceder ao(s) documento(s) a partir de um endereço de IP da instituição detentora da supramencionada licença.

Ao utilizador é apenas permitido o descarregamento para uso pessoal, pelo que o emprego do(s) título(s) descarregado(s) para outro fim, designadamente comercial, carece de autorização do respetivo autor ou editor da obra.

Na medida em que todas as obras da UC Digitalis se encontram protegidas pelo Código do Direito de Autor e Direitos Conexos e demais legislação aplicável, toda a cópia, parcial ou total, deste documento, nos casos em que é legalmente admitida, deverá conter ou fazer-se acompanhar por este aviso.

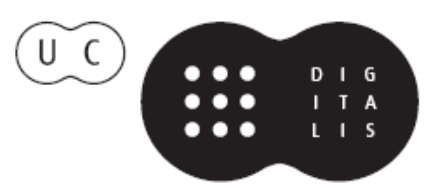




\section{Duarte Nuno Vieira Anthony Busuttil \\ Denis Cusack • Philip Beth}
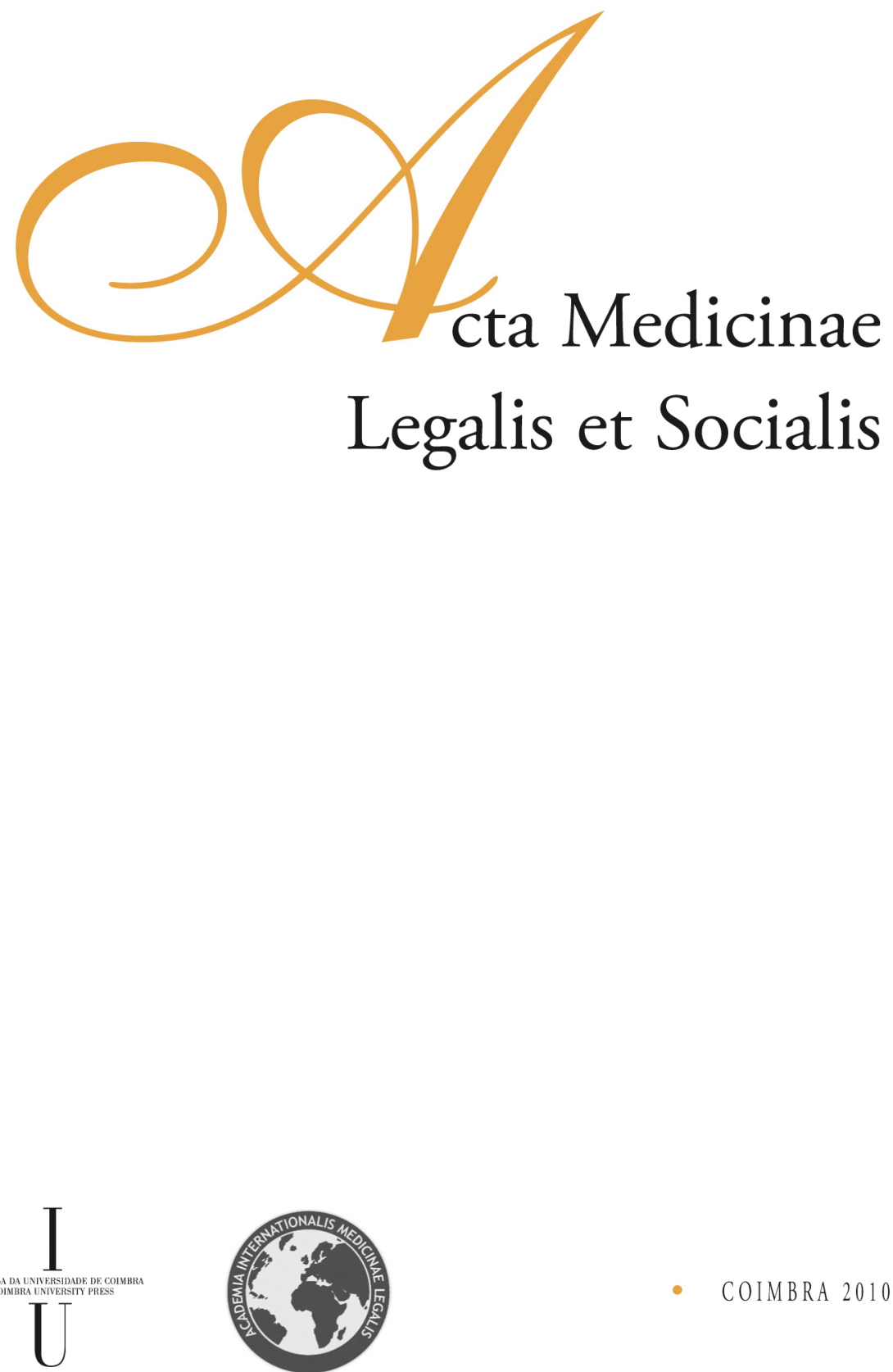
N. Piloto ${ }^{1}$, H. M. Teixeira ${ }^{2}$, E. Teixeira-Lemos ${ }^{1}$, B. Parada ${ }^{1}$, P. Garrido ${ }^{1}$, J. Sereno ${ }^{1}$, A. F. Pinto ${ }^{1}$, E. Costa ${ }^{3,4}$, L. Belo ${ }^{4,5}$, A. Santos-Silva ${ }^{4,5}$, R. Pinto ${ }^{6}$, P. Couceiro ${ }^{7}$, P. Neto ${ }^{8}$, F. Xavier ${ }^{8}$, L. Carvalho ${ }^{7}$, F. Teixeira ${ }^{1,4}$, F. Reis ${ }^{1,4}$

${ }^{1}$ Institute of Pharmacology \& Experimental Therapeutics, IBILI, Faculty of Medicine, University of Coimbra, Portugal

${ }^{2}$ Forensic Toxicology Laboratory, North Branch of the National Institute of Legal Medicine, Oporto,

Portugal

${ }^{3}$ Institute of Health Sciences, Catholic University, Oporto, Portugal

${ }^{4}$ Institute for Molecular and Cellular Biology, University of Oporto, Portugal

${ }^{5}$ Biochemistry Service, Pharmacy Faculty, University of Oporto, Portugal

${ }^{6}$ Pharmacology \& Pharmacotoxicology Unit, Pharmacy School, University of Lisbon, Portugal

${ }^{7}$ Institute of Anatomic Pathology, Faculty of Medicine, University of Coimbra, Portugal

${ }^{8}$ Service of Anatomic Pathology, Coimbra University Hospital, Portugal

\title{
ERYTHROPOIETIN DOPING AS CAUSE OF SUDDEN DEATH IN ATHLETES - AN EXPERIMENTAL STUDY
}

\begin{abstract}
Aims: To evaluate the cardiovascular (CV) effects of rhEPO treatment in rats under chronic aerobic exercise and to assess the probable cause of sudden death in one rat. Protocol: Male Wistar rats: control - sedentary; rhEPO - $50 \mathrm{IU} / \mathrm{Kg} / 3 \mathrm{xwk}$; swimming (EX) $-1 \mathrm{hr}, 3 \mathrm{x} / \mathrm{wk}$; EX+EPO. Haematology, catecholamines and serotonin, redox status and inflammation, were assessed. One rat of EX+EPO group suffered a sudden death episode.

Results: rhEPO treatment in trained rats promoted several markers of increased CV risk. The sudden death rat tissues presented: lungs without signs of drowning; brain with vascular congestion; LV hypertrpphy and deregulation of cardiac fibers, together with a "cardiac liver", suggesting the hypothesis of heart failure as cause of death.

Conclusion: The sudden death of a EX+EPO rat, due to a cardiac episode, together with the increased CV risk profile, strongly suggest a high life risk associated to the continuous rhEPO doping. The anatomo-pathological studies were determinant to establish the cause of death.
\end{abstract}

Keywords: rhEPO; doping; chronic aerobic exercise; sudden death.

\section{Introduction}

Erythropoietin (EPO) is a glycoprotein hormone synthesized predominantly in the kidneys which stimulates proliferation and maturation of erythroid cells in the bone marrow (1). The increase in circulating $\mathrm{RBC}$ may be used to increase $\mathrm{O} 2$ delivery to muscles, improving performance in sport (2). The availability of recombinant human EPO (rhEPO) allowed its use in doping. Sports authorities prohibited the use of rhEPO in 1988. The idea was, first, to limit both the degree of health risk and, second, the degree of performance enhancement. The abusive use of rhEPO promotes an increment of BP, which, together with the increase of Hct and blood viscosity, strengthens the probability of cardio/cerebrovascular events (3). 
In the early 1990s, there was a considerable speculation about the involvement of rhEPO doping in the death of professional cyclists $(4,5)$. The artificial increase in RBC and Hct, further enhanced by dehydratation during prolonged exercise, predisposes to thromboembolic complications, which might be connected to sudden death in sport practice (6). However, the cellular/molecular mechanisms underlying the sudden death episodes are poorly clarified, as well as whether rhEPO use was linked to this outrageous phenomenon.

This study intended to evaluate the CV effects of rhEPO treatment on rats under chronic aerobic exercise; we also studied the probable cause of sudden death occurred in one rat.

\section{Material and methods}

\section{Animals and protocol}

Male Wistar rats (Charles River Lab., Spain), 220-250g, were maintained in appropriate conditioned: $22-24^{\circ} \mathrm{C}$; 60\% humidity; 12-h dark-light cycles; standard rat chow (AO4, Panlab, Letica, Spain) and water ad libitum.

After a period of adaptation of 2 wks, 4 groups $(n=8)$ were tested for 10 wkstreatment: control - sedentary (SED); rhEPO - $50 \mathrm{IU} / \mathrm{Kg} / 3 \mathrm{x} / \mathrm{wk}$ beta-EPO Recormon ${ }^{\circledR}$, Roche Pharm. (EPO); Exercised (EX) - swimming (1 hr, 3x/wk); EX+EPO. The swimming rats were submitted to a 1 wk period of adaptation for minimizing the water stress (bath set at $35 \pm 1^{\circ} \mathrm{C}$ ). Sessions started with $15 \mathrm{~min}$, increased $5 \mathrm{~min} / \mathrm{day}$ until a 60 min continuous period was achieved. Excepting 1 animal of the EX+EPO group, which suffered a sudden death episode during an exercise session (wk 8), all the animals have completed the 10 -week protocol. Body weight (BW) was monitored, and blood pressure (BP) and heart rate (HR) measured.

\section{Sample collection and preparation}

Serum samples were obtained from blood collected with i.p. ketamine anesthesia at the end of treatments. The heart weights (HW) were measured in order to be used as trophy index $(\mathrm{HW} / \mathrm{BW})$. The following tissues were removed from the sudden death rat: lungs, kidneys, brain, heart/left ventricle (LV) and liver and analyzed for histomorphology (H\&E staining).

\section{Haematological data and renal function}

Red blood cell (RBC) count, Hct and haemoglobin (Hb) were assessed by using an automatic Coulter Counter ${ }^{\circledR}$ (Beckman Coulter Inc., USA). Serum creatinine, ureia and uric acid concentrations were assessed through an automatic Hitachi 717 analyser.

\section{Catecholamine and serotonin}

Plasma noradrenaline (NA), adrenaline (A), 5-hydroxy-tryptamine (5-HT) and 5-hydroxy-indoleacetic acid (5-HIAA) concentrations were evaluated by HPLC-ED (7). 


\section{Redox status}

The thiobarbituric acid reactive-species (TBARs) assay was used to assess serum products of lipid peroxidation, via malondialdehyde (MDA), according to previously described (7). Serum 3-nitrotyrosine (3-NT), which is an index of peroxynitrite formation, was measured through an enzymatic immunoassay (HyCult-biotec., Netherlands). Serum total antioxidant status (TAS) was assessed via the ferric reducing antioxidant potential (FRAP) assay (7).

\section{Inflammatory profile}

Serum levels of interleukin 2 (IL-2), IL-1 $\beta$, transforming growth factor $\beta 1$ (TGF- $\beta 1)$, tumour necrosis factor $\alpha(\mathrm{TNF}-\alpha)$ and C-reactive protein (CRP) were measured by Elisa kits (R\&D Systems, USA).

\section{Data analysis}

Results are means \pm s.e.m. Comparisons between groups were performed using one-way ANOVA and Fisher's test. Significance was accepted at $p$ less than 0.05.

\section{Results}

\section{Haematological data and renal function}

$\mathrm{EX}+\mathrm{EPO}$ rats presented a significant $(8.23 \pm 0.14, p<0.05)$ increase in $\mathrm{RBC}$ count vs the EX group (7.59 \pm 0.15$)$. Haematocrit and $\mathrm{Hb}$ showed a trend to identical variation. Exercised rats presented significantly lower values of serum urea $(17.35 \pm 0.26, p<0.05)$ and uric acid $(0.40 \pm 0.06 \mathrm{mg} / \mathrm{dL}, p<0.01)$. This reduction was prevented in the EX+EPO rats $(18.60 \pm 0.63$ and $0.50 \pm 0.03$, respectively).

\section{Blood pressure, HR and heart trophy}

BPs were higher in the EPO group vs control. The same pattern was found for the EX group (SBP: $123.92 \pm 1.38$, DBP: $108.33 \pm 1.34$ and MBP: $113.25 \pm 0.99 \mathrm{mmHg}$; $p<0.05$ and HR: $394.58 \pm 8.66$ beats $/ \mathrm{min})$. The EX+EPO rats presented a further increased in BPs $(136.67 \pm 1.08,123.22 \pm 2.04$ and $127.33 \pm 1.62$, respectively; $p<0.001)$ and HR $(418.44 \pm 6.57, p<0.05)$. HW and HW/BW were significantly higher in the $\mathrm{EPO}$ group vs control. The EX+EPO rats presented a further increment in $\mathrm{HW}$ $(1.40 \pm 0.03 \mathrm{~g}, p<0.01)$ and HW/BW $(3.06 \pm 0.16 \mathrm{~g} / \mathrm{kg}, p<0.05)$ vs EX group $(1.23 \pm 0.03$ and $2.65 \pm 0.10)$.

\section{Catecholamine and serotoninergic measures}

In the EX+EPO rats, the plasma NA $(9.32 \pm 1.43 \mathrm{ng} / \mathrm{ml}, p<0.05)$ and $\mathrm{AD}(1.96 \pm 0.18$, $p<0.05)$ were significantly higher when compared with $\operatorname{EX}(5.10 \pm 0.96$ and $1.04 \pm 0.09)$. Concerning the serotoninergic plasma measures, the EX+EPO rats presented plasma 5 -HT $(30.07 \pm 4.45 \mathrm{ng} / \mathrm{ml}, p>0.001)$ and 5-HIAA $(25.07 \pm 2.38, p<0.05)$ substantially higher than those found in EX $(11.08 \pm 0.65$ and $18.00 \pm 2.94)$. 


\section{Redox status and inflammatory profile}

The EX+EPO rats presented a pro-oxidant effect, with a trend to increased values of serum MDA $(0.34 \pm 0.01 \mu \mathrm{mol} / \mathrm{L}), \mathrm{MDA} / \mathrm{TAS}(1.53 \pm 0.05)$ and 3 -NT $(42.26 \pm 6.90$ $\mathrm{nmol} / \mathrm{L})$ vs $\operatorname{EX}(0.30 \pm 0.02,1.27 \pm 0.09$ and $37.96 \pm 7.31$, respectively).

Concerning the serum inflammatory markers, in the EX+EPO group there was significantly higher values of TGF- $\beta 1(375.7 \pm 23.5 \mathrm{pg} / \mathrm{mL}, p<0.05)$ and a trend to higher values of IL-2 $(59.08 \pm 3.76 \mathrm{pg} / \mathrm{mL})$ vs EX $(317.8 \pm 15.1$ and $51.48 \pm 4.11$, respectively).

\section{Histomorphological analysis of tissues from the sudden death rat (Fig. 1 and Fig. 2)}

The rat HW was $1.82 \mathrm{~g}$ and the HW/BW was 4.04, significantly hypertrophic vs the EX $(1.23 \pm 0.03$ and $2.65 \pm 0.10$, respectively), demonstrating the tremendous effort of the heart to maintain its functions. The histomorphological studies provided the following results: the kidneys (1B1: glomerular and 1B2: tubular) from the suddenly death rat showed eosinophilia and congestion, when compared with control kidneys (1A1 and A2); the lungs showed signs of blood congestion, alveolar hemorrhage and anoxia, without markers of drowning (1B3), vs control (1A3); the brain presented vascular congestion (2B1) vs control (2A1); the liver showed centre-lobular congestion and signals of "cardiac-liver", probably due to the heart failure (2B2) vs the normal pattern of control (2A2); there was LVH and desregulation of cardiac fibers (2A3 vs 2B3), suggesting the hypothesis of heart failure as cause of death.

\section{Discussion}

Since rhEPO became available as an erthropoiesis-stimulating drug, its abusing use by athletes of endurance aerobic sports has been speculated and studied (2,8-10). In endurance sports, such as long-distance running, cycling and skiing, performance relies on an adequate $\mathrm{O} 2$-supply to the heart and skeletal muscle. Hence, the rate of maximal O2-uptake is an important determinant of aerobic physical power. However, athletes who abuse rhEPO seem to consider only the benefit to performance and ignore the short and long-term side-effects. There is a suspicion that rhEPO-induced erythrocytosis caused the death of about 20 world-class cyclists, although this was never proven $(4,5)$, probably due to the lack of methodological capacity to distinguish between the endogenous and the recombinant EPO as well as due the lack of knowledge concerning the mechanisms underlying the side-effects. When Lasne and de Ceaurriz (11) were able to distinguish the endogenous and the rhEPO in human urine, the scandal of rhEPO use in sports was revealed, and the scientific/medical community was able to alert for the high health risks for the athletes.

The main risks of erythrocytosis (Hct>0.55 l/l) include hypertension (HT), heart failure, myocardial infarction and thromboembolic events. Endurance athletes are at increased risk during the competition, if their blood viscosity increases further due to the great loss of fluid associated with sweating $(4,5,9,12)$. Interestingly, some deaths allegedly caused by rhEPO have not occurred during exercise but during periods of physical inactivity, suggesting that the deleterious effects are prolonged. 
In our study, the rats under chronic exercise practice and rhEPO treatment showed several markers of increased CV/thromboembolic risk. The increased RBC count, Hct and $\mathrm{Hb}$ vs EX was confirmed, as expected. This was accompanied by development of HT and tachycardia. Increased BP is a common feature in patients and athletes under rhEPO treatment $(8,9,13)$, and might result both from hyperviscosity and loss of hypoxia-induced vasodilatation. rhEPO treatment was also able to promote heart hypertrophy, which might be due to the blood hyperviscosity and could be viewed as a need to ensure proper blood circulation to peripheral tissues. Increased tachycardia might be explained by the increment in sympathetic activity, revealed by the increment in plasma NA and AD. This effect of rhEPO was previously documented, namely on hemodialyzed patients under rhEPO therapy (14). Furthermore, there was an increment in plasma 5 -HT, which might result from platelet overactivation, thus releasing the granule contents. The increased platelet reactivity was reported by others (3), and is in favour of an increased BP and thromboembolic complications.

rhEPO has been successfully used in anaemic patients to correct their anaemia. However, its effects on non-hematopoietic cells and tissues, such as the brain and the heart, suggested new important insights to its use in other pathological conditions, such as the ischemia-reperfusion, heart failure and neurodegenerative diseases (15). The rationale for its potential use in those disorders is based on its antioxidant, antiapoptotic and anti-inflammatory properties, already known as "pleiotropic actions" (16). In our study, both the rhEPO treatment (per se) and the exercise practice have demonstrated a beneficial effect on the redox status markers. However, rhEPO use in rats under exercise favoured oxidative stress, given by the higher MDA/TAS index and 3-NT content, which, considering the deleterious effect of ROS, represent an increased risk. This pattern was accompanied by a trend to higher values of IL-2 and CRP, and a significant increment in TGF- $\beta 1$. While the increase in the proliferation marker TGF- $\beta 1$ might eventually explain the heart hypertrophy, the increase in IL-2 and CRP suggest an inflammatory effect, further strengthening the deleterious actions of rhEPO treatment in situations of regular exercise.

All the changes reported for the EX+rhEPO rats seem to be in agreement with the sudden death episode occurred in one rat of the group, after $8 \mathrm{wks}$ of protocol. Actually, the rhEPO treatment in trained rats promoted an increase in RBC count (contributing to hyperviscosity), HT, heart hypertrophy, sympathetic and serotonergic overactivation, as well as oxidative stress and inflammation. The anatomo-pathological tissue evaluation of a suddenly death rat, demonstrated that there were no drowning signs in the lungs, despite some congestion marks. The kidneys showed some eosinophilia and the brain revealed vascular congestion. Furthermore, and even more relevant, there was some LVH and deregulation of cardiac fibers, together with a "cardiac liver", suggesting the hypothesis of heart failure as the cause of death, which is in agreement with the increased risk of cardio/cerebrovascular and thromboembolic events that the functional studies in the $\mathrm{EX}+\mathrm{EPO}$ also indicate. 


\section{Conclusion}

The sudden death of a rat belonging to the Ex+EPO group, due to a cardiac episode, together with the increased CV risk profile, strongly suggest a high life risk associated to the continuous rhEPO doping. The anatomo-pathological studies were determinant to establish the cause of death.

\section{References}

JELKMANN W. Molecular biology of erythropoietin. Intern Med, 43:649-459, 2004.

ELLIOTT S. Erythropoiesis-stimulating agents and other methods to enhance oxygen transport. Br J Pharmacol, 154:529-541, 2008.

STOHLAWETZ PJ, DZIRIO L, HERGOVICH N, et al. Effect of erythropoietin on platelet reactivity and thrombopoiesis in humans. Blood, 95:2983-2989, 2000.

GAREAU R, AUDRAN M, BAYNES RD, et al. Erythropoietin abuse in athletes. Nature, 380: 113, 1996.

THEIN LA, THEIN JM, LANDRY GL. Ergogenic aids. Phys Ther, 75:426-439, 1995.

ADAMSON JW, VAPNEK D. Recombinant human erythropoietin to improve athletic performance. N Eng J Med, 324:698-699, 1991.

BAPTISTA S, PILOTO N, REIS F, et al. Treadmill running and swimming imposes distinct cardiovascular physiological adaptations in the rat: focus on serotonergic and sympathetic nervous systems modulation. Acta Physiol Hung, 95:235-251, 2008.

ROBINSON N, MANGIN P, SAUGY M. Erythropoietin abuse in sports. Sysmex J Int, 13:75-77, 2003.

BENTO R, DAMASCENO L, NETO F. Eritropoietina recombinante humana no esporte: uma revisão. Rev Bras Med Esporte, 9:169-180, 2003.

CRUZ A. Resistência aeróbia e eritropoietina. Goiânia, 33: 553-572, 2006.

LASNE F, de CEAURRIZ J. Recombinant human erythropoietin in urine. Nature, 405:635 (2000)

CAZZOLA M. A global strategy for prevention and detection of blood doping with erythropoietin and related drugs. Haematologica, 85:561-563, 2002.

GAUTHIER J. Effets cardiovasculaires du dopage. Ann Cardiol Angeiol (Paris), 50293:8 (2001)

TORRALBO A, HERRERRO JA, PORTOLÉS J, et al. Activation of the sympathetic nervous system in hemodialyzed patients treated with erythropoietin. Nephron, 69:350, 1995.

MAIESE K, LI F, CHONG ZZ. New avenues of exploration for erythropoietin. JAMA, 293:90-95, 2005.

MANOLIS AS, TZEIS S, TRIANTAFYLLOU K, et al. Erythropoietin in heart failure and other cardiovascular diseases: hematopoietic and pleiotropic effects. Curr Drug Targets Cardiovasc \& Haematol Dis, 5:355-375, 2005. 

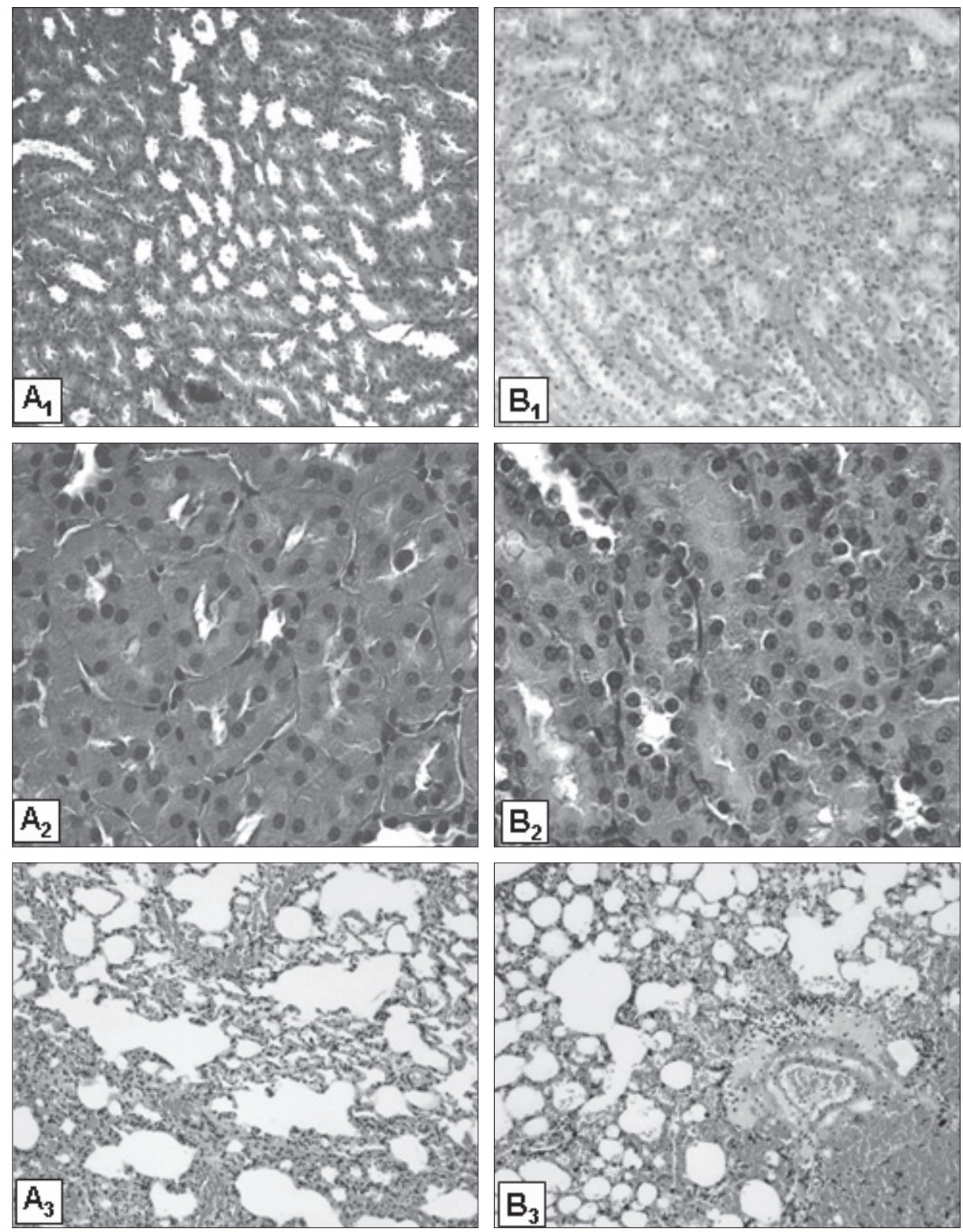

Figure 1 - Histomorphological H\&E staining pictures from the kidney glomerular (1) and tubular

(2) regions and from the liver (3) from the control rats (A) when compared with those of the sudden death rat of the EX+EPO group (B). 

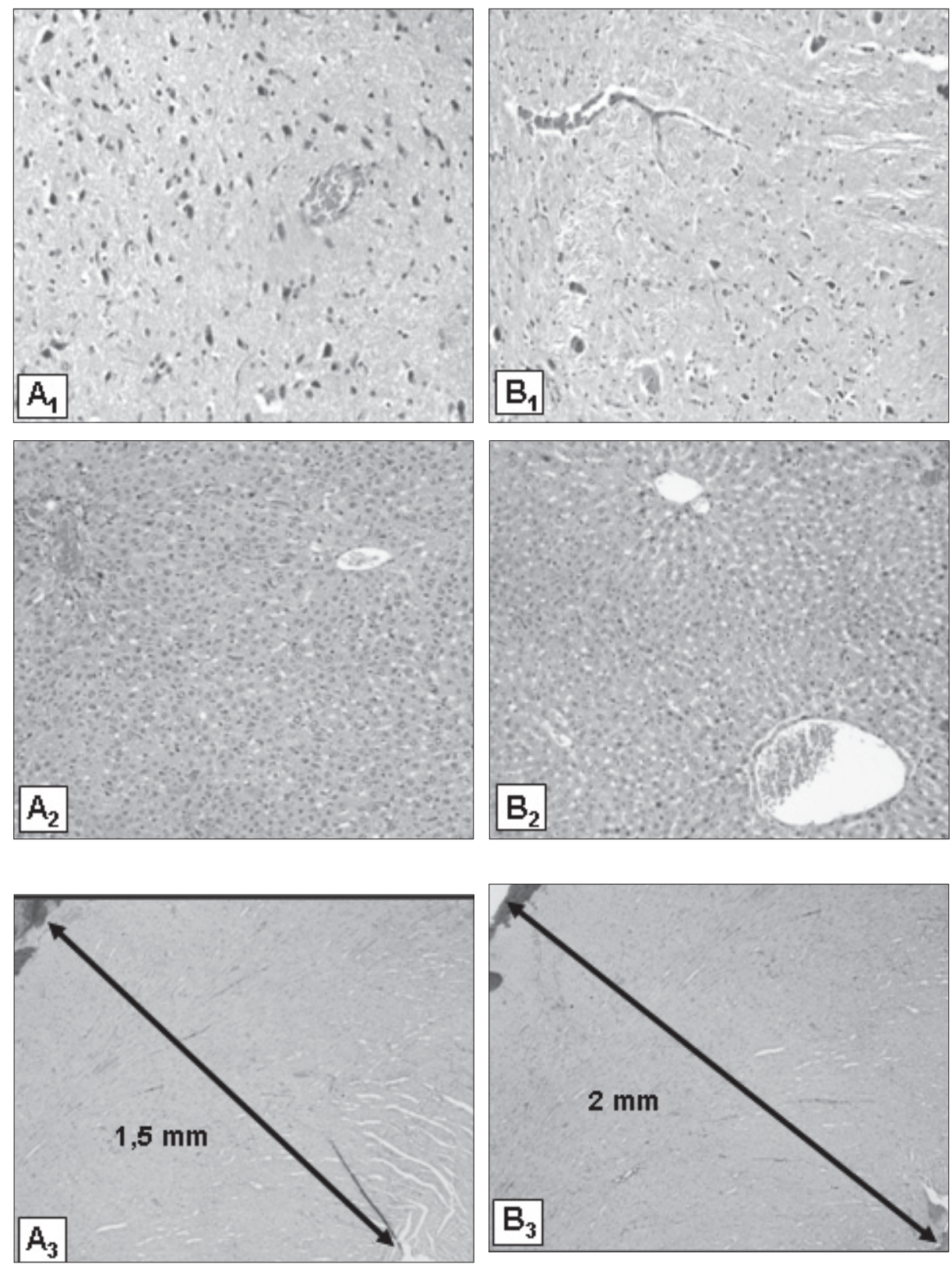

Figure 2 - Histomorphological H\&E staining pictures from the brain (1), the liver (2) and the left ventricle (3) from the control rats (A) when compared with those of the sudden death rat of the $\mathrm{EX}+\mathrm{EPO}$ group (B). 